\title{
"I Liked the Post on our Page": The Relevance of Content and User Participation to Facebook Pages of Faith Communities
}

\author{
Jacob Dankasa \\ (College of Information, University of North Texas, Denton, Texas, USA)
}

\begin{abstract}
Many churches have Facebook pages, but a good number of these pages may not be engaging enough for the users because of the absence of research data that could help managers of these pages to provide the type of content relevant to their audiences in an evolving social media platform. Despite several studies on the use of social media by non-profit organizations, not much is done about how religious organizations can effectively utilize particularly Facebook pages to promote their religious practices through providing appropriate user content. This study describes the participation and expectations of users of faith community Facebook pages. It draws out the type of content users prefer to see shared on their faith community Facebook pages to motivate their interest and increase participation. A survey that utilized both closed and open-ended questions was administered to members of Catholic churches in the Dallas, Texas, area in the United States who use Facebook. A Simple Taxonomy of content-type was developed. Users show the need for content that is informing, educating, entertaining, spiritual and connecting. The study provides data and strategies for new media evangelization in faith communities. This study contributes to the literature of user studies in the social network domain that may drive the development of effective social media platforms for religious communities.
\end{abstract}

Keywords: Social media, Facebook pages, online social networks, new media evangelization, faith community

\section{INTRODUCTION}

The evolution of Facebook pages has opened the way for businesses, organizations and interest groups to expand and build community for their customers or members. Apart from being a forum for interaction and socializing, this is also an opportunity for businesses to strengthen their brand and widen their reach (Holzner, 2008; Orsini, 2010; Patterson, 2012; Shih, 2009). Furthermore, organizations and interest groups use Facebook pages to transmit information and promote their causes. Awareness of users' characteristics and expectations is primary in determining the right information to be transmitted (Savulescu \& Mihalcea, 2013).

Developing the ability to reach a targeted audience is not only essential for businesses, but it is also necessary for religious institutions. Religious organizations are considered non-profit, and there are several studies on the use of Facebook by different types of non-profit organizations (Gould, 2015; Waters, Burnett, Lamm, \& Lucas, 2009). However, not much is done about how religious organizations can effectively utilize particularly Facebook pages to promote their religious practices through providing appropriate user content.

Many churches have Facebook pages, but a good number of these pages may not be engaging enough for the users because of the absence of research data that could help managers of these pages to provide the type of content relevant to their audiences in an evolving social media platform. This lack of data and the resulting poor content quality of church Facebook pages may lead to user inactivity and an unwillingness to participate. According to Savulescu and Mihalcea (2013), 'relevant and interesting content encourages interaction and fan retention' (p. 42). Therefore, there is a need to understand the users of Facebook pages of faith communities, their characteristics, their impressions about their pages, the contents, and how such Facebook pages can be improved to serve their needs.

This study investigated how users participate on church Facebook pages and their expectations on the type of contents relevant to such pages. It describes the participation and level of engagement of users of church Facebook pages. It draws out the type of contents these users prefer to see shared on their Facebook pages to motivate their interest and increase participation. The study answered the following questions: (a) How do members of faith communities participate on church Facebook pages, (b) What type of content do members of faith communities expect on a church Facebook pages?

One major aim of this study is to create awareness of the need to pay attention to the content and interactivity of Facebook pages of faith communities. The study may help those responsible for managing social media of religious institutions to be aware of what information is relevant for a religious audience on online social networks, and what type of communication styles can be applied to keep members engaged and interested in order to increase participation on these pages. This study may be of relevance to church pastors, administrators, communications directors and others who are responsible for disseminating religious 
"I Liked the Post on our Page": The Relevance of Content and User Participation to Facebook ..

information through social media pages. It provides strategies on how best to engage users of social networks in faith communities. The study may also provide data to researchers of social media use in communities for comparing user needs from diverse perspectives.

\section{RELATED WORK}

There is no shortage of studies on the uses and users of Facebook as a social media tool for a variety of purposes. Users of Facebook have been studied to determine their characteristics, including factors such as the influences of gender and age on patterns of use (Fogel \& Nehmad, 2009; Guadagno, Muscanell, Okdie, Burk, \& Ward, 2011). Several recent studies have found an increasing presence of older adults on social networks (Muscanell \& Guadagno, 2012; "Pew Research," 2014), unlike studies in the past in which the use of the Internet for social networking was attributed to the young. Some studies have investigated different personality types of users and how their traits impact social relationships online (Bachrach, Kosinski, Graepel, Kohli, \& Stillwell, 2012; Ross et al., 2009), while others have found online social behavior to reflect the offline behavior of the user (Gosling, Augustine, Vazire, Holtzman, \& Gaddis, 2011; Lampe, Ellison, \& Steinfield, 2008). Most of the data concerning characteristics of these users come from domains such as education (Meishar-Tal, Kurtz, \& Pieterse, 2012), health care (Young, Szekeres, \& Coates, 2013), marketing and business enterprise (Hsu, 2012; Kwok \& Yu, 2013), and workplaces (Vitak, Lampe, Gray, \& Ellison, 2012). Users of online social networks from religious domains have not been given much attention.

Two very important features of Facebook are the pages and the group functions. The uses and applications of Facebook pages and group features have been investigated in several studies (Al Mamun, Ibrahim, \& Turin, 2015; Bender, Jimenez-Marroquin, \& Jadad, 2011; Glazer, 2012; Parsons, 2011; Xia, 2009). Some studies have examined the benefits of Facebook pages in relation to academic learning. In a recent study, Daugherty, Broghammer, DeCosmo, Giberson, and Birnbaum (2015) examined the uses and gratification that first year students of a university derived from the use of Facebook pages. They found that students use these pages to learn, to seek information and to build community. The aim of the authors was to help institutions of learning find the best ways of recruiting students and engaging them through Facebook pages. Another study found that entertainment, socializing, seeking information, and self-status are primary reasons why some people participate in Facebook groups (Park, Kee, \& Valenzuela, 2009). According to Valerio, Herrera-Murillo, Villanueva-Puente, Herrera-Murillo, and del Carmen Rodríguez (2015), higher learning institutions are continuously using Facebook pages to achieve the goal of teaching by exploring new methods of pedagogy and to promote their institutional appeal.

Facebook pages are widely used by various organizations and interest groups to achieve the aims of information dissemination, building community and promoting causes (Forman, Kern, \& Gil-Egui, 2012; Poyry, Parvinen, \& Malmivaara, 2013; Reichenbach, 2014). Larsson and Kalsnes (2014), for instance, studied how politicians use their Facebook pages to achieve their political goals. The business sector seems to know how best to utilize Facebook pages to achieve competitive advantage and to market their brands. In several studies, the use of Facebook pages to grow business have been demonstrated (Jothi, Neelamalar, \& Prasad, 2011; Michaelidou, Siamagka, \& Christodoulides, 2011; Miller \& Lammas, 2010). To achieve success with users, businesses who use Facebook pages must notice how their customers use their pages. Chen, Papazafeiropoulou, Chen, Duan, and Liu (2014) found that ease of access to a Facebook page without technical difficulties influences the customer's perception of the brand and increases loyalty. They recommend that users' experience on Facebook pages should not be taken for granted. Unfortunately, studies examining the experience of users of church Facebook pages are lacking. No sufficient data are available for managers of Facebook pages in faith communities to use in determining what contents best fit their audience. This study attempts to provide such data.

Although several studies have been conducted to determine how users of Facebook pages and groups use these features from perspectives such as business, academics, politics and non-profit organizations, not much is known about users in religious communities as non-profits. Studies on Facebook use by non-profit organizations (Waters, Burnett, Lamm, \& Lucas, 2009) could contain useful data for religious organizations; however, it must be noted that religious domain is unique, due to its emphasis on faith and a supernatural being. This emphasis may cause users to interact with church Facebook pages in a manner that is different from their interactions with other non-profits on Facebook. This sets the church Facebook page apart from other non-profit platforms. Therefore, there is a need for separate studies concentrating on Facebook pages in their religious domain.

Studies on how members of religious organizations use the social media are few (Frye, 2012; Keppler, 2012; Rosch, 2011). One of the few studies (Keppler, 2014) examined the users of Facebook pages belonging to religious institutions and the gratification that users obtained from using the pages. The study found that members are motivated to use their church Facebook pages for information and entertainment, or to find inclusion in the community. The findings also indicate a slightly higher level of gratification with their religious 
"I Liked the Post on our Page": The Relevance of Content and User Participation to Facebook ..

experience among members who used their church's Facebook pages, as opposed to those who did not. Although Keppler (2014) pointed out some characteristics of users of church Facebook pages, more studies are needed to determine the amount of participation of users on these pages and their preferred contents. Knowing more about the users and their preferences will help in reshaping the Facebook pages of faith communities.

\section{METHOD}

A survey that utilized both closed and open-ended questions was administered to members of Catholic churches in the Dallas, Texas, area in the United States who use Facebook.

\section{Participants}

Two hundred ten Facebook users participated in the study, but a total of 178 participants responded that they belong to a church Facebook page and were used for analysis. Among them, 23.6\% were males and 76.4\% females; $15.7 \%$ were ages $18-29,41.6 \%$ were ages $30-49,29.8 \%$ were ages $50-64$, and $12.9 \%$ were 65 years or older. The ethnicity of the participants was 75.3\% Caucasian, 16.3\% Hispanics/Latino, 3.4\% Asians, $1.7 \%$ Africans, $1.7 \%$ Native Americans, $0.6 \%$ African Americans and 1.1\% others. For their general use of Facebook, $38.2 \%$ reported they use Facebook less than an hour a day, $42.1 \%$ use it between 1-2 hours a day, 15.7 said they use Facebook 3-4 hours a day, while 4\% reported they use Facebook over 5 hours a day.

\section{Data Collection}

A link to the questionnaire was posted on the church Facebook pages of several Catholic parishes. The same link was also posted on the author's private timeline on Facebook, and the privacy setting was adjusted to share only with users from Dallas. The author has previously created custom and smart friends' lists based on Facebook users from the Dallas area. The post provided an explanation of the purpose of the study and requested that users take the survey. One question of the survey asked: Are you a member of any Catholic community in the Dallas area? Those who answered no were excluded from the study. The section of the survey reported in this paper wanted to find out how members of faith communities who belong to their church Facebook pages participate in the activities of the page, and their perception and recommendations on the type of contents provided in these Facebook pages. Therefore, it concentrated on users who either follow or like a church Facebook page in order to draw from their experience of these pages. To determine such users, a question in the survey asked: Do you belong to a church Facebook page? Two options were provided: yes or no. This question was meant to screen for the participants who are users of church Facebook pages. Those who answered no were excluded from the analysis.

In addition to demographic questions of age, gender, ethnicity and religious affiliation, two questions asked about participation on church Facebook pages. These questions asked participants on a Likert scale ranging from 1 (Never) to 5 (Always) to rate the statements: I read the posts on my church Facebook page; I have commented or liked a post on my church Facebook page. Another question wanted to know the satisfaction level of participants with their church Facebook page. Using a Likert scale ranging from 1 (Very dissatisfied) to 5 (Very satisfied), they were to rate their level of satisfaction with the question: Overall, how satisfied are you with your church Facebook page? To determine how active participants are in their general use of Facebook, a question was asked: Approximately, how much time do you spend using Facebook a day? The following options were provided: less than an hour, 1-2 hours, 3-4 hours, 5-6 hours and more than 6 hours.

Two open-ended questions were asked in order to find out the expectations of users on the type of contents they would like to see on their church Facebook pages and how the pages can be improved. The two open-ended questions were: 1) What do you like the most about your church Facebook page? 2) What improvement do you want to see on your church's Facebook page?

\section{Data Analysis}

The closed-ended questions were analyzed using simple descriptive statistics such as frequency counts. The responses to the open-ended questions were imported into NVivo qualitative data analysis software and the data were analyzed and placed into categories by the researcher. Descriptive coding was used for the analysis. In descriptive coding, themes from participants' responses are identified and created as categories from the meaning given to these statements (Saldaña, 2013). Using descriptive coding, five categories-informing, educating, entertaining, spiritual and connecting - were developed after a thorough examination of the data. A coding scheme was developed based on the description of these five themes. Responses of the participants were placed under a particular category that fits certain criteria as described in the scheme (see Table 1).

In the process of analyzing the data, another separate category was developed. This new category was found to differ from the five categories that explain the content preference of participants. This category was developed from responses of participants that did not fall into the initial five categories. These responses suggest a need for effective church Facebook page management. This latter category was named page management. 
"I Liked the Post on our Page": The Relevance of Content and User Participation to Facebook..

Table 1 Presents the coding scheme used to determine the responses that go into various categories. After all the responses were placed under a category, similar responses within each category were merged together to form summaries of participants' expectations on church Facebook pages.

Table 1. Coding Scheme and Inter-Coder Reliability

\begin{tabular}{|c|c|c|c|}
\hline Category & Coding Scheme & $\begin{array}{l}\text { Kappa } \\
\text { coefficient }\end{array}$ & $\begin{array}{l}\text { Percent } \\
\text { agreement }(\%)\end{array}$ \\
\hline Informing & $\begin{array}{l}\text { Responses that express the need for information, updates } \\
\text { and news of events and happenings in the local } \\
\text { community }\end{array}$ & 0.81 & 90.8 \\
\hline Educating & $\begin{array}{l}\text { Responses that express the need for teachings and } \\
\text { positions of the church }\end{array}$ & 0.81 & 90.8 \\
\hline Spiritual & $\begin{array}{l}\text { Responses that express the need for prayers and interest } \\
\text { in spiritual messages }\end{array}$ & 0.80 & 91.1 \\
\hline Entertaining & $\begin{array}{l}\text { Responses expressing the need for visual representation } \\
\text { of events }\end{array}$ & 0.48 & 72.2 \\
\hline Connecting & $\begin{array}{l}\text { Responses that express the need for building relationship } \\
\text { and community through interactions among members and } \\
\text { groups }\end{array}$ & 0.91 & 95.6 \\
\hline $\begin{array}{l}\text { Page } \\
\text { Management }\end{array}$ & $\begin{array}{l}\text { Responses that mention expectations of the duties of the } \\
\text { page administrator and the need for relevant and frequent } \\
\text { updates }\end{array}$ & 0.79 & 90.6 \\
\hline
\end{tabular}

After the researcher had coded the different participants' responses into the created categories, a second coder who has experience with coding was contacted to conduct an independent coding of the responses. This was to ensure inter-rater reliability. The second coder was given all the responses from the two open-ended questions. The responses comprise mostly brief statements or sentences. The responses to the two questions were merged together because both questions were meant to collect data to explain a similar concept - the type of contents users expect or prefer to see on church Facebook pages. The scheme used as criteria for the coding of the data into the categories as given on Table 1 was also explained and presented to the second coder. His task was to determine what responses go into the six categories developed by the researcher, following the criteria in Table 1.

The coding of the second coder was entered into the NVivo software as a second user. Percent agreement and Kappa coefficient were used to assess inter-rater reliability using NVivo software. Kappa coefficient was expected to be .70 or higher because it is known to be conservative. Otherwise, a liberal percent agreement index of .90 or higher was expected. According to Cohen, kappa value 0.01-0.20 is considered as none to slight agreement, $0.21-0.40$ is fair, 0.41-0.60 is moderate, 0.61-0.80 is substantial and 0.81-1.00 is considered as almost perfect agreement (McHugh, 2012). The kappa values found here were all acceptable based on Cohen's recommended level of agreement. The inter-rater reliability result for the six categories are given in Table 1.

\section{RESULTS}

This study examined two research questions: (a) How do members of faith communities participate on church Facebook pages, (b) What type of content do members of faith communities expect on a church Facebook pages? The findings are presented below.

\section{How Members of Faith Communities Participate on Facebook pages Reading Post on Church Facebook Page}

The first part of the study intends to find out how users who are members of faith communities participate on their church Facebook pages. Participants were asked to rate the frequency with which they read the posts made on their church Facebook pages. The results of the frequency analysis show that a combined total of $26.9 \%$ reported that they either rarely or sometimes read the posts on their church Facebook page, $37.1 \%$ said they often read the posts, and $36 \%$ reported that they always read the posts on their Facebook page $($ mean $=$ 4.02, $S D=0.91, N=178)$.

\section{Commenting or Liking Post on Church Facebook Page}

Another question requested that participants rate how frequently they comment or like a post on their church Facebook pages. From frequency analysis, 6.7\% reported that they have never commented or liked a post 
"I Liked the Post on our Page": The Relevance of Content and User Participation to Facebook..

on their church Facebook pages; a combined total of $51.11 \%$ said they either rarely or sometimes comment or like a post on their Facebook page; 28.7\% said they often do, and 13.5\% reported that they always comment or like a post on their church Facebook page. (mean $=3.25, S D=1.10, N=178)$.

\section{Satisfaction with Church Facebook Page}

Participants were asked to describe how satisfied they are with their church Facebook pages. Frequency analysis revealed that $23 \%$ are very satisfied with their church Facebook pages, $44.4 \%$ reported they were satisfied, while $25.8 \%$ were neutral. Only a combined total of $6.1 \%$ reported that they were either dissatisfied or very dissatisfied with their church Facebook pages ( mean $=3.82, S D=.91, \mathrm{~N}=178$ ).

\section{Types of Content Users Expect on Church Facebook Pages}

Participants were asked in two open-ended questions to write what they like the most about their church Facebook pages and the improvements they would like to see on these pages. This was to determine the type of contents that are most important and useful to the users of church Facebook pages. The different points the participants provided were analyzed and placed under five themes created as categories: informing, educating, entertaining, spiritual and connecting. The five categories show that the users of church Facebook pages expect contents that are informing, educating, spiritual, entertaining and connecting. The distribution of participants' responses on the type of contents they expect to see on church Facebook pages based on the categories developed is given in Figure 1.

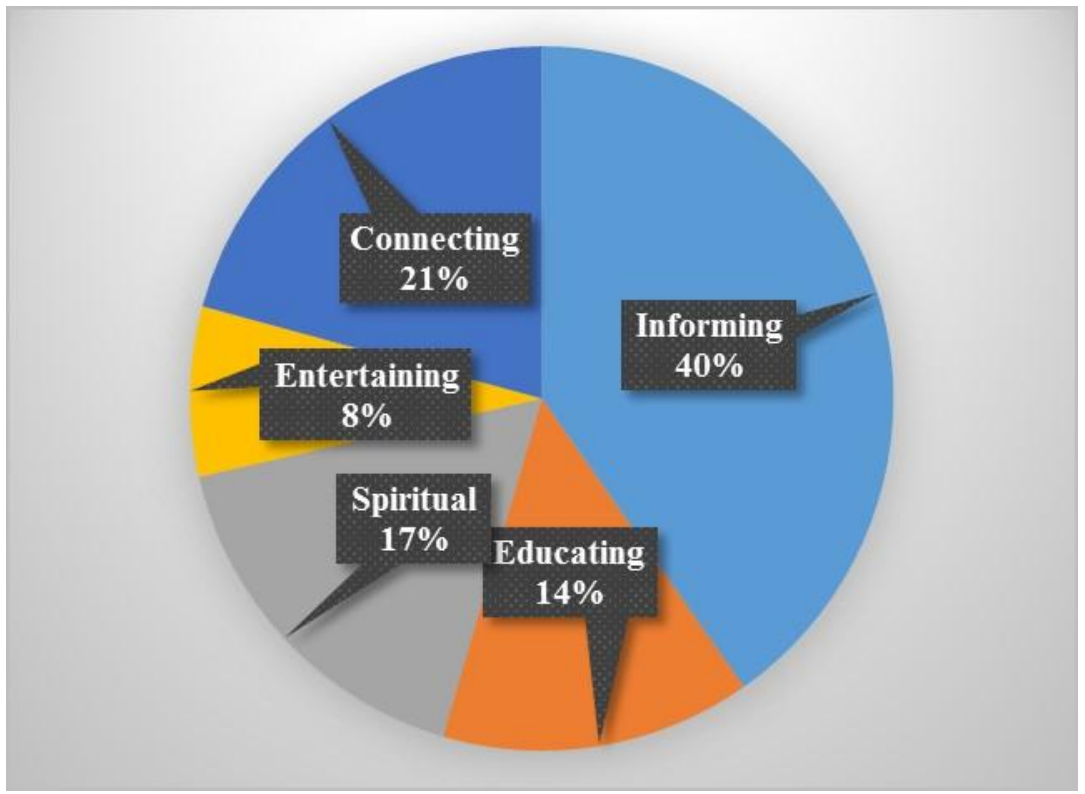

Figure 1. A distribution of user expectations of content-type for faith community Facebook pages

Another category that did not fall into the class of content-type was created as the data were examined. This category was named page management. The five categories on the content-type and the separate category on page management are discussed below.

\section{Informing Content}

Participants expressed the need for contents that are informative on their church Facebook pages. For some users, the Facebook page is where they go to find updated information about events and activities going on in their parish community. Many participants suggested that the page should be constantly updated with information on events, the parish schedule of activities, mass times and information about the ministries and organizations in the parish. According to one participant:

[I] would like to see more posts about ... other organizations in the church (outreach). As a new mom, I am not sure what groups may be available to me at this new stage of life.

There are participants who think the Facebook page is a more convenient place to find information than the weekly bulletin because some access Facebook several times a day. A participant stated that the church Facebook page is a "convenient form of information and I am more likely to go to events" that are listed there. 
"I Liked the Post on our Page": The Relevance of Content and User Participation to Facebook..

\section{Educating Content}

Participants expressed a desire for more contents that are educational on their church Facebook pages. Areas most important to them are teachings on church issues and the faith. The types of educational contents they want include posting of links to blog posts where the clergy and other experts explain and discuss important religious topics. They are interested in articles, documents and relevant materials related to the positions and teachings of the church on very important issues such as the sacraments, and moral and social issues. There was a strong emphasis on teachings about family life. One participant expressed that the church Facebook page should provide: informative basic education for novice or possible new members, as well as bible studies and opportunities for online chats.

\section{Entertaining Content}

Participants also expressed the need for contents that are entertaining on their church Facebook pages. The responses in this category were mostly centered around providing photos and videos of events and activities that take place in the local church community. Expressing how photos and videos are important to some users, one participant referred to a priest in a parish who shares photos on Facebook, thus: "I like that when he travels, he shares his experiences with us." Participants showed interest in having a visual representation of the community's activities on their pages to keep them entertained, and to also share in the beauty of their community.

\section{Spiritual Content}

The responses of the participants in this category indicate that they like seeing spiritual contents on their church Facebook pages and would want to see more of such contents. The types of spiritual contents include inspirational messages, daily reflection on the life of the saints, and the need for prayer boards on Facebook pages. This need was expressed by one participant thus: "I would love to see a prayer board so I can pray for other's concerns in the community." The participants also emphasized the need to provide scripture and short sermons in which all the priests in the parish are featured in order to have some variety of reflections/sermons from the priests.

\section{Connecting Content}

Some of the participants elaborated on how they feel about using church Facebook pages and their concerns with their church Facebook pages. Many expressed the need for increased connection. These participants indicated that the Facebook page connects them with their community and members in different ways. The desire for more connection shows that some users derive benefits from participating on their church Facebook pages. One participant wrote that she is "unable to drive due to illness and [Facebook] helps me be part of my church." Another participant explained the connecting benefits of the church Facebook page:

It's a way for me to stay connected. My life is very hectic with full time job and responsibilities for elderly mother. I can't be involved as I would like due to lack of any free time. The FB [Facebook] page helps.

Some participants called for improvement on this aspect. They expressed concerns with how members of the church, especially the Catholic church (who constitute the sample in this study), use their Facebook pages and with their lack of active participation. A participant lamented that the Catholic audience is so apathetic about its participation on church Facebook pages:

I think I'm the only person in our large parish who comments or reads or participates through our FB [Facebook] page. I'm an adult convert from evangelical background. I find Catholics to be introverted in ministries, outreach, etc., which may explain why they are averse. This is the same with other [Catholic] churches and the diocesan pages.

They suggest the need for more interaction and participation of members on the page, the ability to ask questions and receive answers, and the need to establish connection with young adults of the community.

A theme that was developed from the data but did not fall into the five categories presented above, due to its focus on the management of the page, is discussed below.

\section{Page Management}

An important finding that concerns managing the Facebook page surfaced. Users stressed the need for frequent updates, and commented on how managers of the church social media communication should give attention to learning how to effectively use the platform. The following summarized participants' responses on how administrators could manage the church Facebook page to enhance user experience.

- Frequent updating and posting of variety of contents should be a priority.

- Information should be current and relevant.

- Page administrators should be active in responding to comments or questions.

- The Facebook page should be advertised and promoted. 
"I Liked the Post on our Page": The Relevance of Content and User Participation to Facebook..

- The page should always appear on the newsfeed.

The findings also indicate that some church social media managers may not be familiar with how to use the tools of the new technology. One participant, who also reported being the coordinator of parish communication for one of the Catholic parishes, expressed frustration with how the Facebook page as a communication tool is handled as an afterthought by some of the Catholic parishes. In the view of this participant, the parish managers seem not to pay attention to the reality and importance of the new technology communications tools available for the churches' use in improving the communication process in an evolving age of the social media. According to this participant, referring to the Facebook page:

I am the first to admit we probably don't use it enough as a communication tool. I'm not even sure we have the settings correct in order to be using it as effectively as we could. I currently take care of the Bulletin, the website, the digital signage, Facebook page, and Constant Contact campaigns, and [I]work with ministries on developing graphics and publicity campaigns for their events. I try my best but often feel like a Jack-of-alltrades but a master of none. In reaching out to my contemporaries I find that is one of the biggest flaws in parish communications - one person wears so many hats that it is hard to create a really quality product, and the parishes do not want to invest the money in hiring someone who really knows what they are doing. In my case I was willing to serve, and had some working knowledge of desktop publishing and basic graphic design, so gradually all the pieces became my domain. Don't get me wrong, I love what I do, just sometimes I feel like I'm working in the dark...I know just enough to get the job done, but not enough to really get it done right. Most of what I've learned over the years has been self-taught. But then the more I learn, the more I find I need to learn. There is just so much information out there, that constantly changes, and I have so little time left over to explore and learn. In talking to others involved in communications for their parishes I find they have the same frustrations... I still have lots of questions on the best techniques to use on it.

This section presents the findings of the study showing the development of five themes that described users' expectation of content-type on church Facebook pages, and another theme describing participants' views on the management of the page. The following section discusses the findings.

\section{DISCUSSION}

This study seeks to describe the level of users' participation and engagement on Facebook pages of faith communities and to determine their preferences on the type of contents they want to see shared on those pages. The findings show that users are more likely to read the post on their church Facebook pages than to comment on or like the post. Many participants reported reading posts frequently or often on their pages, but only a few reported commenting often or always. While $37.1 \%$ reported to often and $36 \%$ to always read the post on their Facebook pages, only $28.7 \%$ said they often and $13.5 \%$ said they always commented on or liked a post on their church Facebook page. This indicates less user interaction with the contents of their Facebook pages. Users tend to read the information and messages on their pages when they appear on their newsfeed, but the sense of community interaction, in which users participate by commenting on posts, is lacking. The result is not surprising, considering that the comment boxes of many church Facebook pages are mostly empty. There is a low level of participation and engagement by members in the conversation on the Facebook pages.

When users rarely interact with their Facebook pages by making comments on the posts shared on those pages, Facebook becomes a one-way broadcast communication model; this is a characteristic of the older or traditional media. Social media, on the other hand, is expected to be more interactive, taking the form of a one-to-one, one-to-many and many-to-many model of communication. The lack of active interaction shown in this study could be the result of redundant posts that do not draw the interest of users. When the postings become redundant, users do not find them engaging and may stop following. Knowing the type of contents that will keep users interested and engaged is very important in turning Facebook into an extension of the real-life brick-and-mortar church community.

The findings from the open-ended section of this study show how beneficial the Facebook page can be for some members of the church. Many participants expressed the benefits of the Facebook pages for them. Although some users derive gratification from the use of their church Facebook pages, many call for improvement. The findings reveal the preferences of users on the type of contents provided on these pages. Several comments were given by participants on what they like about their Facebook pages, and recommendations were made concerning the improvements that need to be made. The findings show five types of contents that are relevant to users of faith community Facebook pages. According to these users, the contents of these pages should be informing, educating, entertaining, spiritual and connecting. These five themes make up what is described in this study as a taxonomy of content-type for faith community Facebook pages (see Table 2). 
"I Liked the Post on our Page": The Relevance of Content and User Participation to Facebook..

\section{The Need for Informing Content}

The need for contents that are informing appears to be the dominant need for this group of users. Among the recommendations for improvement are issues that involve frequent updates and the types of information provided. Contents of the posts shared on faith community Facebook pages are very important to the users. Some users conveyed that the Facebook page is a convenient method of getting information about church events, and that they are more likely to go to such events when they see them posted on their page. Therefore, these contents should be relevant to the local community and related to their growth in faith. The Facebook page should provide frequently updated information about the activities, schedules and events of the local community. Church members want to know more about the organizations and ministries in their churches. Some participants believe that the Facebook page would be a good platform to showcase briefings about the ministries and organizations. The Facebook pages could showcase brief video messages from each ministry or organization in the community explaining what they do and how members can participate.

Table 2. A Simple Taxonomy of the Type of Content Expected on Faith Community Facebook Pages as Identified by Users

Informing Content

- Provide updates about ongoing church events/mass times/deaths/funerals, etc.

- Provide information about the various church ministries/organizations/groups and links to the various ministries from the church web page

- Promote events of the local community

- Provide links to other church news sites, such as the diocesan or Vatican news

- Post parish reminders

- Provide reliable and up-to-date information about the community

* Educating Content

- Post relevant topics related to the positions and teachings of the Church on important issues of faith and religion

- Initiate and facilitate thoughtful discussion on important issues about the Church and society

- Provide links to posts by the Pope, the bishop and the clergy of the parish, and links to other religious blogs with relevant topics related to the faith

- Provide more articles for young people on the faith and sacraments

- Provide teachings on family life and posts for parents about faith formation

* Entertaining Content

- Provide frequent and timely updates with photos and videos of church events and sharing of personal happenings

* Spiritual Content

- Post topics on spiritual growth/daily spiritual and bible quotes

- Provide inspirational messages and daily reflections on the lives of the saints, inspiring stories and resources for improving spiritual life

- Provide scripture and short sermons, and feature all the clergy of the faith community and post their messages and reflections/sermons to have some variety

- Establish a prayer board so members of the faith community can request prayers and pray for the needs and concerns of others in the community

* Connecting Content

- Enhance more connections and interaction among members and the community

- Encourage more interaction of clergy and people

- The page should establish a connection with the young adult ministry

- Connect the different segments of the church community- the school, staff, parishioners and clergy

- Enhance the ability to ask questions and receive answers

\section{The Need for Connecting Content}

The need for connection is second to the need for information. Users want their community Facebook page to be a forum that connects them to the community and to one another. Therefore, they suggest the posting of contents that enhance connection and draw members to participate. According to these users, their faith community Facebook page makes them feel more connected to the church. They expressed the need for the church Facebook pages to be more interactive, not just a one-way communication. Many users of church Facebook pages in this study are asking for more connections with members. They want content providers in these pages to encourage members' participation by providing thought-provoking and engaging discussions. One participant emphatically wrote: 
"I Liked the Post on our Page": The Relevance of Content and User Participation to Facebook ..

Make it more interactive or reflective, challenge people's views, take them out of their comfort zones.

The desire for connection prompts the suggestion that faith community Facebook pages need to be more inviting to all demographics. In the view of some participants, not much attention is given to young people on these pages. Therefore, it is essential for churches and religious communities to create separate Facebook pages targeting the younger audience if the presence of older adults and the content they prefer makes younger users uncomfortable or fails to hold their interest. Audience fragmentation is very important in the social media in making messages relevant. The social media business model on audience fragmentation, based on the rules of online marketing on social network sites suggested by Savulescu and Mihalcea (2013), can be equally applied to the Facebook pages of faith communities. This model is achieved by "targeting specific consumers (based on demographic and behavioral profiles that SNSs provide), adapting the message to them and making it consistent" (p. 49). Managers of social media communications in religious organizations must not ignore this need to reach out to the younger audience.

\section{The Need for Spiritual Content}

Another important preference for these users is the need for contents that are spiritual. The need for spiritual contents on faith community Facebook pages sets it apart from other non-profit Facebook pages. Users want to enrich their spirituality through this social media means of communication. They need their Facebook pages to provide them with inspirational messages and reflections on the scriptures and the lives of the saints. They want the forum to be not only for social purposes, but also for growth in their faith and spiritual journey. These participants express the unique aspects of such pages when they suggest the need for a prayer board where community members can request prayers from others and share their spiritual moments with the community. This type of desire on social media leads to a call for developing a local parish spirituality where members of a church community can participate in growing the spirituality of other members whom they may not have known or met in real-life church.

\section{The Need for Educating Content}

The findings also show the need for contents that are educational. The type of education that participants in this study referred to here is mostly education on their faith, the Church and religion. Users want their church community to provide them with the Church's position on pressing issues in the society and in their lives. They see their faith community Facebook page as a place to gain information and to learn about the Church, the faith, and the community. The page should contain links to blogs and pages of their clergy and religious leaders. There should be more frequent posting of relevant topics about the positions and the teachings of the Church, especially on controversial moral or social issues. Users of these pages want to see an increased presence of their parish clergy on their Facebook pages to explain issues and feed them with answers on questions about the faith. They want to see more posts from their clergy. These users appreciate reading posts from the clergy and seeing the clergy communicating with their members. They want to be able to ask questions and receive answers through their Facebook pages because they are accessible and provide anywhere, anytime interaction with their community. The Facebook page of faith communities should be a medium for teaching, educating, communicating, interacting and learning about the faith.

\section{The Need for Entertaining Content}

The results of this study also show the need for contents that are entertaining, although this category was less stressed than the previously discussed categories. However, it underscores the need of this audience to also find fun in their community. The users expressed the need for photos and videos of events held in their local community to be posted on their church Facebook page. Some participants believe the Facebook page keeps them more informed with photos and parish events than the weekly bulletin. These users expect to see more photos of parish events. Some participants commented that they feel uplifted and enjoy the fact that when their priest travels he shares his experiences of his trip with them in photos through the Facebook page. These are important features that need to be taking into consideration in designing a faith community Facebook page that meets the needs of this particular audience.

\section{IMPLICATIONS AND CONCLUSION}

The findings of this study show that the contents of social networks of faith communities based on user needs may differ somewhat from the type of contents desired by users on other non-religious sites. For instance, the simple social media taxonomy developed in this study differs in composition and focus from the social media taxonomy for business-related social networks developed by Gordon (2013). Gordon presented six content types in his taxonomy: to inform, to educate, to entertain, to communicate, to collaborate and to transact. Some of the categories found in this study are similar to those in Gordon's taxonomy. However, the desire for spiritual contents and the focus of the categories found in this study set the social media of faith communities 
"I Liked the Post on our Page": The Relevance of Content and User Participation to Facebook..

apart from other settings. This is evident in the findings that show the type of contents needed to inform and to educate on church Facebook pages to be related to the users' desire to learn about the teachings of their faith and to connect with the activities of their local faith community. This also indicates that, although a large amount of research already exists concerning the use of social media for both profit and non-profit organizations, the content needs of users may not be generalized across all contexts. Therefore, this study argues that the social media of faith communities is unique, different from other settings in content-type, and needs to be studied within its context of use. Unfortunately, not many studies exist on the use of social media by faith communities. This makes the findings of this study very important. It lends support to Kwok and Yu (2015), who proposed careful planning and research for non-profits in various contexts in order to develop social networking relationships with their particular users.

This study can be considered a need analysis that could drive the design of an effective Facebook page with contents that meet the user needs of members of faith communities. The findings of this study have several implications for directors of church communications, social media managers, youth directors and pastors of churches. The study provides data that may help improve communication processes in religious organizations using online social network pages such as Facebook for new media evangelization. Examining the recommendations of users of church Facebook pages shows that there is a need to develop ways to make the user experience more interactive in order to build a sense of community among members who use the page.

Managers of social media networks in faith communities need to pay attention to the issues and suggestions raised in this study. There are some users who mentioned that the page does not always appear on their newsfeed. It is possible that they may not be aware of the settings that allow them to set their Facebook page so that it always appears on their newsfeed when a new post is made. It is the responsibility of the page managers to help users be aware of such useful settings. Unfortunately, the findings of this study indicate that some directors and managers of communications in religious communities may not be very familiar with using the features of the social media, and may have some challenges in using the tools of the evolving new technologies. This calls for active engagement. Therefore, to respond to these challenges, religious organizations need to establish a parish communication directors' network that meets periodically across their dioceses or organizations. In these meetings, technical aspects may be introduced to the members in order to provide them with more tools that will help them to be familiar with the best practices in social media communications. This will also provide an opportunity for networking that will enhance learning through peers.

The findings of this study also show the need for religious organizations to invest time and resources in taking advantage of the many benefits that the social media bring to the changing methods of communication in a world saturated by the influence of technology. Therefore, churches and other religious organizations should consider employing full-time directors of communications with expertise in the use of new media technology to meet the challenges of modern communications for effective new media evangelization. The study also shows the need for the clergy to actively participate in building this online community.

Although the study has some limitations because it was based on self-report data, it nevertheless contributes to the literature of user studies in the social networks domain. It draws attention to the uniqueness of members of faith communities in their use of the social media for religious purposes. The study creates an understanding of religious Facebook page users in order to develop a faith community social media platform. Future study may observe actual activities of participants on a social media platform and compare the findings with the present study.

About the Author:

Jacob Dankasa holds a master's degree in Mass communications from St. Cloud State University Minnesota, USA and $\mathrm{PhD}$ in Information Science from University of North Texas, Denton, USA.

\section{REFERENCES}

[1] Al Mamun, M., Ibrahim, H. M., \& Turin, T. C. (2015). Social media in communicating health information: An analysis of Facebook groups related to hypertension. Preventing chronic disease, 12. doi: http://dx.doi.org/10.5888/pcd12.140265

[2] Bachrach, Y., Kosinski, M., Graepel, T., Kohli, P., \& Stillwell, D. (2012). Personality and patterns of Facebook usage. Paper presented at the Proceedings of the 4th Annual ACM Web Science Conference, New York. doi: 10.1145/2380718.2380722

[3] Bender, J. L., Jimenez-Marroquin, M. C., \& Jadad, A. R. (2011). Seeking support on facebook: a content analysis of breast cancer groups. Journal of medical Internet research, 13(1). Retrieved from http://www.jmir.org/2011/1/e16/

[4] Pew Research Center. (2014). Social networking fact sheet. Retrieved from http://www.pewinternet.org/fact-sheets/social-networking-fact-sheet/ 
"I Liked the Post on our Page": The Relevance of Content and User Participation to Facebook..

[5] Chen, H., Papazafeiropoulou, A., Chen, T. K., Duan, Y., \& Liu, H. W. (2014). Exploring the commercial value of social networks: Enhancing consumers' brand experience through Facebook pages. Journal of Enterprise Information Management, 27(5), 576-598. Retrieved from http://dx.doi.org/10.1108/JEIM-05-2013-0019

[6] Daugherty, J., Broghammer, R., DeCosmo, A., Giberson, P., \& Birnbaum, M. (2015). Perceived benefits of participation in the "class of" Facebook pages. The Journal of Social Media in Society, 4(1), 152-176.

[7] Fogel, J., \& Nehmad, E. (2009). Internet social network communities: Risk taking, trust, and privacy concerns. Computers in Human Behavior, 25(1), 153-160. doi:10.1016/j.chb.2008.08.006

[8] Forman, A. E., Kern, R., \& Gil-Egui, G. (2012). Death and mourning as sources of community participation in online social networks: RIP pages in Facebook. First Monday, 17(9).

[9] Frye, S. B. (2012). Religious distance education goes online. New Directions for Adult and Continuing Education, 2012(133), 13-22. doi:10.1002/ace.20003

[10] Glazer, H. (2012). "Likes" are lovely, but do they lead to more logins? Developing metrics for academic libraries' Facebook pages. College \& Research Libraries News, 73(1), 18-21.

[11] Gordon, I. H. (2013). Managing the new customer relationship: Strategies to engage the social customer and build lasting value. Ontario, Canada: John Wiley \& Sons.

[12] Gosling, S. D., Augustine, A. A., Vazire, S., Holtzman, N., \& Gaddis, S. (2011). Manifestations of personality in online social networks: Self-reported Facebook-related behaviors and observable profile information. Cyberpsychology, Behavior, and Social Networking, 14(9), 483-488. doi:10.1089/cyber.2010.0087

[13] Gould, M. (2015). The social media gospel: Sharing the good news in new ways. Collegevile, MN: Liturgical Press.

[14] Guadagno, R. E., Muscanell, N. L., Okdie, B. M., Burk, N. M., \& Ward, T. B. (2011). Even in virtual environments women shop and men build: A social role perspective on Second Life. Computers in Human Behavior, 27(1), 304-308. doi:10.1016/j.chb.2010.08.008

[15] Holzner, S. (2008). Facebook marketing: leverage social media to grow your business. Indianapolis, IN: Que Publishing.

[16] Hsu, Y. L. (2012). Facebook as international eMarketing strategy of Taiwan hotels. International Journal of Hospitality Management, 31(3), 972-980. doi:10.1016/j.ijhm.2011.11.005

[17] Jothi, P. S., Neelamalar, M., \& Prasad, R. S. (2011). Analysis of social networking sites: A study on effective communication strategy in developing brand communication. Journal of media and communication studies, 3(7), 234-242.

[18] Keppler, C. C. (2012). Facebook and the church: Using social media to communicate traditional messages. Paper presented at the annual meeting of the Ohio Communication Association, Kent, $\mathrm{OH}$.

[19] Keppler, C. C. (2014). Facebook and the Church: Gratifications Sought and Gratifications Obtained. (Master's thesis, University of Akron). Retrieved from http://rave.ohiolink.edu/etdc/view?acc_num=akron1401890272

[20] Kwok, L., \& Yu, B. (2015). Taxonomy of Facebook messages in business-to-consumer communications: What really works?. Tourism and Hospitality Research, Published online before print August 14, 2015, doi: 10.1177/1467358415600214

[21] Kwok, L., \& Yu, B. (2013). Spreading Social media messages on Facebook: An analysis of restaurant business-to-consumer communications. Cornell Hospitality Quarterly, 54(1), 84-94. doi: $10.1177 / 1938965512458360$

[22] Lampe, C., Ellison, N. B., \& Steinfield, C. (2008). Changes in use and perception of Facebook. Paper presented at the Proceedings of the 2008 ACM conference on Computer supported cooperative work., New York. doi: 10.1145/1460563.1460675

[23] Larsson, A. O., \& Kalsnes, B. (2014). 'Of course we are on Facebook': Use and non-use of social media among Swedish and Norwegian politicians. European Journal of Communication, 29(6), 653667.

[24] McHugh, M. L. (2012). Interrater reliability: The kappa statistic. Biochemia medica, 22(3), $276-282$. Retrieved from http://www.ncbi.nlm.nih.gov/pmc/articles/PMC3900052/

[25] Meishar-Tal, H., Kurtz, G., \& Pieterse, E. (2012). Facebook groups as LMS: A case study. The International Review of Research in Open and Distributed Learning, 13(4), 33-48.

[26] Michaelidou, N., Siamagka, N. T., \& Christodoulides, G. (2011). Usage, barriers and measurement of social media marketing: An exploratory investigation of small and medium B2B brands. Industrial Marketing Management, 40(7), 1153-1159. Retrieved from 10.1016/j.indmarman.2011.09.009

[27] Miller, R., \& Lammas, N. (2010). Social media and its implications for viral marketing. Asia Pacific Public Relations Journal, 11(1), 1-9. 
"I Liked the Post on our Page": The Relevance of Content and User Participation to Facebook..

[28] Muscanell, N. L., \& Guadagno, R. E. (2012). Make new friends or keep the old: Gender and personality differences in social networking use. Computers in Human Behavior, 28(1), 107-112. doi:10.1016/j.chb.2011.08.016

[29] Orsini, M. (2010). Facebook... for Business? Caring: National Association for Home Care magazine 29(2), 42-43. Retrieved from http://merrilyorsini.com/wpcontent/uploads/2010/04/100201_CARING.pdf

[30] Park, N., Kee, K. F., \& Valenzuela, S. (2009). Being immersed in social networking environment: Facebook groups, uses and gratifications, and social outcomes. CyberPsychology \& Behavior, 12(6), 729-733. doi:10.1089/cpb.2009.0003

[31] Parsons, A. L. (2011). Social media from a corporate perspective: A content analysis of official Facebook pages. Paper presented at the Proceedings of the academy of marketing studies, 16(2), 11.

[32] Patterson, A. (2012). Social-networkers of the world, unite and take over: A meta-introspective perspective on the Facebook brand. Journal of Business Research, 65(4), 527-534. doi:10.1016/j.jbusres.2011.02.032

[33] Poyry, E., Parvinen, P., \& Malmivaara, T. (2013). The Power of 'Like'--Interpreting Usage Behaviors in Company-Hosted Facebook Pages. Paper presented at the System Sciences (HICSS), 46th Hawaii International Conference, Wailea, Hawaii. doi: 10.1109/HICSS.2013.535

[34] Reichenbach, K. (2014). Using content analysis to examine the relationship between commercial and nonprofit organizations motives and consumer engagement on Facebook. (Doctoral dissertation, University of Missouri). $\quad$ Retrieved from https://mospace.umsystem.edu/xmlui/bitstream/handle/10355/45686/research.pdf?sequence=1\&isAllo wed $=\mathrm{y}$

[35] Rosch, D. (2011). Churches increasingly fans of Facebook, other social media. Retrieved from http://www.christianpost.com/news/study-churches-increasingly-fans-of-facebook-social-media-48591/

[36] Ross, C., Orr, E. S., Sisic, M., Arseneault, J. M., Simmering, M. G., \& Orr, R. R. (2009). Personality a nd motivations associated with Facebook use. Computers in Human Behavior, 25(2), 578-586.

[37] Saldaña, J. (2013). The coding manual for qualitative researchers (2nd ed.). Los Angeles: Sage Publications, Inc.

[38] Savulescu, R. M., \& Mihalcea, A. D. (2013). Social networking sites: Guidelines for creating new business opportunities through Facebook, Twitter and Linkedin. Management Dynamics in the Knowledge Economy, 1(1), 39-53.

[39] Shih, C. (2009). The Facebook era: Tapping online social networks to build better products, reach new audiences, and sell more stuff. Boston, MA: Prentice Hall.

[40] Valerio, G., Herrera-Murillo, D. J., Villanueva-Puente, F., Herrera-Murillo, N., \& del Carmen Rodríguez, M. (2015). The relationship between post formats and digital engagement: a study of the Facebook pages of Mexican universities. Universities and Knowledge Society Journal, 12(1), 50-63. doi: http://dx.doi.org/10.7238/rusc.v12i1.1887

[41] Vitak, J., Lampe, C., Gray, R., \& Ellison, N. B. (2012). “Why won't you be my Facebook friend?”: Strategies for managing context collapse in the workplace. Paper presented at the Proceedings of the 2012 iConference, New York. doi: 10.1145/2132176.2132286

[42] Waters, R. D., Burnett, E., Lamm, A., \& Lucas, J. (2009). Engaging stakeholders through social networking: How nonprofit organizations are using Facebook. Public relations review, 35(2), 102-106.

[43] Xia, Z. D. (2009). Marketing library services through Facebook groups. Library management, 30(6/7), 469-478. doi:http://dx.doi.org/10.1108/01435120910982159

[44] Young, S., Szekeres, G., \& Coates, T. (2013). Sexual risk and HIV prevention behaviours among African-American and Latino MSM social networking users. International journal of STD \& AIDS, 24(8), 643-649. doi: 10.1177/0956462413478875 